\title{
Linguistic Landscape of the City of Rijeka during the Socialist Federal Republic of Yugoslavia
}

\author{
Marina Rončević1, Mladen Marinac ${ }^{2}$ \\ Polytechnic of Rijeka, Rijeka, Croatia
}

\begin{abstract}
This paper examines multilingual usage and cultural pluralism in the public life of the city of Rijeka in the historical period from 1945 to 1990. That is the period after the Second World War, the era of the Socialist Federal Republic of Yugoslavia (SFRY), marked by the emergence of a new collective identity. The aim of the study is to investigate the level of influence of political, economic and social changes on language usage and the choice of language(s) in the period of advanced industrialization, urbanization and globalization using an interdisciplinary approach, that is contemporary linguistic anthropological and sociolinguistic research that deals with the issue of cultural and language diversity of multicultural and multilingual environments. The paper focuses on the analysis of dynamics of pragmatic and symbolic dimensions of language usage in the city's history. It is based on the historical analysis of signs of the lingusitc landscape by exploring archive materials and popular newspapers for that period. In order to achieve that, the method of deliberate sampling was used. It seems that political and language ideology is reflected in signs of the lingustic landscape. Thus, given the small number of Italians, the emerging bilingualism (Croatian-Italian) gradually disappeared. Based on the analysis of signs, those languages that are used in the langauge community of Rijeka are part of its lingusitc landscape. Furthermore, it is possible to speak about bilingual, however not multilingual population.
\end{abstract}

Keywords: multilingualism, linguistic landscape, preferred languages 


\section{Introduction}

The phenomenon of language manifests in multiple spatial, social and functional variations, which are subject to social changes and are classified into specific phenomena and forms. The basic function of language is communication among people; the exchange of thoughts, ideas, and experiences, feelings, given that language reflects everything that is happening in a community, all changes in political, economic and cultural sphere. Language, also, reflects the current ideology. Language ideologies are important both for the social and linguistic analysis. They connect the social structure with the language. Language ideologies indicate and determine the connection between the language and the group, personal identity, estetics, moral and epistemiology. The role of language ideology comes to the fore in societies where groups of speakers are unequal, or during colonial conquests.

Language as a social category reflects the identity of the community itself, which is manifested in signs of the lingusitc landscape. The linguistic landscape reflects what the identity of the city really is, identity of people who live in that city, their mututal relationships, origin and power relations that are in place. The term linguistic landscape was first used by Landry and Bourhisin (1997:25) who define linguistic landscape in the following way: "The language of public road signs, advertising billboards, street names, place names, commercial shop signs and public signs on government buildings combines to form the linguistic landscape of a given territory, region, or urban agglomeration."

Their definition is very precise in pointing out the focus of the study - signs in public spaces. From the semiotic point of view our world is a world of signs and symbols, and without them communication would be impossible. Since all signs are signs of communication in different languages, together they form the linguistic landscape of a particular area.

Itagi and Singh (2002b; ix) define the concept of the linguistic landscape in a broader way. The terms Linguistic Landscape /Landscaping (LL) are defined as "language use in its written form (visible language) in the public sphere." Their conception of the term 'linguistic landscape' slightly deviates from the definition of Landry and Bourhis (1997) in that it includes potential study objects items such as newspapers, visitingcards, and other print media. (Itagi and Singh, $2002 \mathrm{~b}$; ix) This definition points to studying linguistic landscapes from a diachronic aspect that helps us see the wider framework of language use in a particular public space and wider area in the past.

\subsection{Signs}

It is known that sign is a key term in semiotics. From a semiotic point of view, the world we live in is a world of signs and symbols. Without them, no communication would be possible at all as all of these signs are also part of communication signs encoded in various languages constructing, thus, the linguistic landscape of an area. Given that a sign is a key term in semiotics, a semiotic sign contains an inherent meaning about something which is not necessarily identical with the sign itself. A sign is usually physical in its nature like sound or image. All we know about our surroundings is based on emitting and interpreting signs. According to Backhaus (2007), a sign in context of the linguistic landscape is: "A sign was considered to be any piece of written text within a spatially definable frame. The underlying definition is physical, not semantic. It is rather broad, including anything from the small hand written sticker attached to a lamp-post to huge commercial billiboards outside a department store. An item such as 'push' and 'pull' stickers at entrance doors, lettered foot mats, botanic 
explanation plates on trees, were considered to be signs, too. Each sign (...) was counted as one item, irrespective of its size" (Backhaus, 2007: 66).

Signs allow us to determine the multilingualism of a place. The analysis should take into consideration where signs come from, who they address, the period and the political situation of their conception. Indeed, different time periods have different signs. The development of the sign is at the same time the development through time. A diachronic change of the linguistic landscape can be noticed by continuous observation of signs in various time units for the same place. Comparing then the signs from various time-lapses, a diachronic development of the linguistic landscape can be obtained. The linguistic landscape is, also, strongly connected to a language policy. In this regard, Leclerc (1989) differentiates signs created by the government from signs created by private initiative. Those signs which are created by national authorities are referred to as top-bottom, whereas those created upon private initiative are called bottomup (Backhaus, 2007).

In the analysis of the motives behind the publication of signs, Ben-Rafael (2009) distinguishes four primary motives: self-presentation, good reason, power relations and collective identity. The self-presentation primarily refers to those signs which, by its linguistic distinctiveness, express the individual identity of those who placed them. Good reason points to the idea that language usage on signs matches the expectations of its audience. By power relations, language usage is determined by dominant ethnic and linguistic groups, whereas collective identity is about the affirmation of minority languages present on signs for those belonging to nondominant groups. The choice of language itself, the order and position of languages on multilingual signs illustrates a linguistic situation in a given social context. Signs themselves have both an informative and a symbolic role. The informative function of signs, especially in cases of multilingualism, provides information about the number of languages present in a given territory, whereas the order and the visibility or marginalization of languages on the same signs says about their relevance. As to the symbolic function, the presence of a given language in signage in public spaces can indicate that the language, in a given sociolinguistic context, is positively evaluated and that it has a respectable status. This can increase the aptitude of its speakers to use the language more often and in a wider context of communication. On the other hand, the absence of a language in the linguistic landscape gives the impression that the language is not perceived positively, which could in turn discourage language usage by its speakers. The symbolic function of the linguistic landscape is, in this sense, connected to ethnic-linguistic vitality. 


\subsubsection{Rijeka during the Socialist Federal Republic of Yugoslavia (1945-1990)}

Rijeka is a city with an extremely turbulent history. Its revival, but also tangible multilinguality and multiculturism wese recorded during the Austro-Hungarian Monarchy (1868 - 1918). After the downfall of the Monarchy, the city came under Italy (1918 - 1943), that is Germany during the Second World War, which was the period of stagnation and decline.

The period after the Second World War represents the beginning of an absolutely new state structure, thereby also the birth of a new collective identity, the author of which was the state. During the Socialist Federal Republic of Yugoslavia (SFRY), the identity of the city was changing. By the end of the Second World War on 10 February 1947 by the Peace Treaty in Paris, Rijeka and Istria were officially returned to the People's Republic of Croatia, later Socialist Republic of Yugoslavia. The SFRY was founded on the basis of self-governing socialism, communist ideology and national liberation struggle. It consisted of six republic and six constituent peoples, and five official languages and two scripts (Latin and Cyrilic). Rijeka was part of The Republic of Croatia, with the official Croatian language and Latin script. During the People's Republic of Yugoslavia, later Socialist Federal Republic of Yugoslavia, the identity of the city changed. Multilingualism was not represented to that extent, but after a long period in history in Rijeka Croato-Serbian became the dominant language with emphasis on collective identity which forms the state.

The presence of multilingualism (the German and English language), besides the Italian language, occurred only in the domain of tourism. The Italians who were earlier autochtnous population became a national minority, with the right to express their belonging and language use, as well as education, in the Italian language. At the very beginning, bilingual signs (Croatian and Italian) were dominating, however this came to an end given that a huge number of Italians left Rijeka.

Figure 1: Banners (celebration of 1st of May 1947)

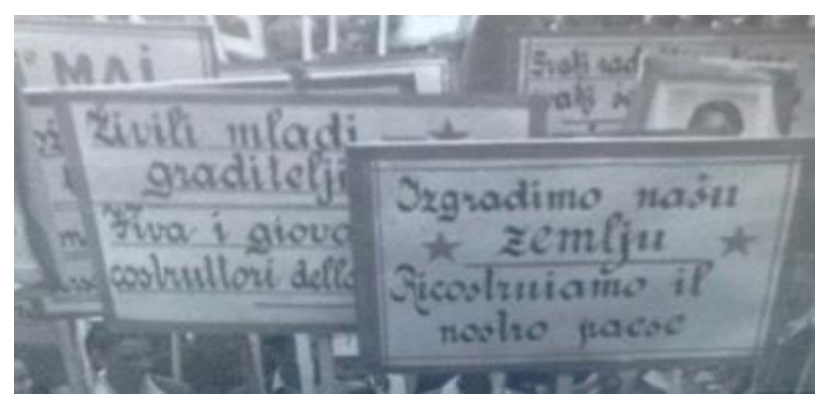

Source: The 2016 outdoor exhibition on Korzo, Rijeka, Croatia.

Namely, political change of the regime was reflected in the population structure. The status of Italians and Germans in Yugoslavia was not enviable. The Paris Peace Treaty made possible for the Italian population in Istria and Rijeka freedom of choice, that is the right to choose between Yugoslavian nationality and remaining or keeping the Italian nationality and leaving for Italy. A considerable number of Italians, Croats and Slovenians left Rijeka. The reasons for leaving were two-fold. One part of population left beacuse they were connected to the prior Fascist government, and the other part consisted of autochtonous people of Rijeka 
"Fijumani", which were in the Rijeka area for generations and which considered themselves native to Rijeka, but did not accept the newly-formed regime.

Besides the mass emigration, the process of immigration of population was under way. Many moved from closer and farther Croatian regions, which chageed the city identity. Political tendencies were visible in the 1981 census where it was possible to see a sudden growth in the quota of the Yugoslavinians (17.0\%) in relation to the Croatian population (64.9\%). There was a tendency toward the development of collective consciousness based on self-governed socialism and the inheritance of the national liberation struggle. After the war, Rijeka was developing industrially and it became a strong transport hub, the main and biggest porti $\mathrm{n}$ the state, and one of the strongest industrial centers of Croatia. Rijeka was developing in the cultural and artistic area as well, but also in the area of tourism.

At the end of 1980s the political situation in Yugoslavia became more complex. There was a tendency toward a new way of life, new trends and the national Croatian identity was awoken, while on the other side everything was suppressed and smothered. In that manner, in 1991 the war broke out in Croatia caused by Serbian agression together with the Yugoslav People's Army that was trying to conquer the whole area.

\section{Methodology}

One possible method to investigate the public life of the city of Rijeka during the SFRY is to apply a diachronic perspective to its linguistic landscape. Linguistic landscape research of an area is based on the analysis of language used on public signs displayed in public space. The presence of one or more languages indicates the sociolinguistic structure of a given territory, which according to Landry and Bourhis (1997) makes the informative function of the linguistic landscape. The symbolic function, on the other hand, along with assessing the ownership of the sign, determines language dominance and, hence, power in a multilingual community. However, the present study was carried out on the economic, culture and political situation of a given historic period for the given area. In a diachronic analysis, not only the known historic data are taken into consideration, but also articles from various newspapers. For the purpose of this paper, the authors have studied the time-lapse from 1945 to 1990.

The research was carried out by adopting the method of deliberate sampling, or, as Edelman (2010) called it, the method of diversity or heterogeneity sampling. Firstly, this method was applied because it allows for generalization of conclusions from the collected samples. Secondly, it was used to obtain a larger range of the linguistic landscape which would also include some unusual linguistic landscapes. The same method had already been put in use by Ben-Rafael et al. (2004, 2006), Edelman (2010) and Hübner (2006). For the purpose of this paper the authors used 100 collected samples that were found in archival material and postcards. The samples have been then divided with respect to their nature: official, social and private foreign signs. Namely, official signs mainly refer to traffic-regulatory labels and official names of city institutions. The social sign was differentiated from the official one due to its reference to signs that are in public ownership, which was the basis of the economy back then because the term private sign refers to services (cafes, restaurants) and trades (shoemakers, tailors, saloons and hairdressers) becuase private ownership in the other form did not exist. The private foreign sign refers to signs from abroad in which foreign companies advertise their products in newspapers in Rijeka. 
The difference in interpretation of the three kinds of signs points to language policy and language ideology of the time. In order to conduct the analysis, 20 variables were introduced for the period of the the Socialist Federal Republic of Yugoslavia. The most relevant variables were chosen and examined: official, private and social signs, type of discourse, presence of collective identity marks, verbal and iconic, number of languages on the sign, and order of appearance of the languages.

\section{Results and Discussion}

By examining the linguistic landscape of public areas from the diachronic point of view from 1945 to1991, social changes and transformations at different levels, from very fast to very slow and gradual, were detected and intepreted. According to Landry \& Bourhisu (2007), the lingusitc landscape has an informative and symbolic function. In our case that means that by analyzing signs of the Rijeka linguistic landscape from the end of the Second World War until the fall of the SFRY and foundation of the independent Republic of Croatia, we are going to pinpoint to the informative and symbolic function of the language on signs.

In relation to sign types, the majority of analyzed signs (56.4\%) were social signs. These are followed by private signs (18.8\%), foreign private signs (12.9\%), and official signs $(11.9 \%)$.

Table 1: Sign type

\begin{tabular}{|l|c|c|}
\hline Institution type & Frequency & Percentage \\
\hline Official sign & 12 & 11.9 \\
\hline Foreign private sign & 13 & 12.9 \\
\hline Social sign & 57 & 56.4 \\
\hline Private sign & 19 & 18.8 \\
\hline Total & 101 & 100.0 \\
\hline
\end{tabular}

Source: Authors

The names of public institutions were written in the Croatian language. The names of institutions advertised under the foreign sign were in Italian, such as "Coin", "Upim". Italian and German department stores advertise Italian and German products in local newspapers in Croatian. These papers do not address an Italian or German minority, given that everything is in the Croatian language, but all citizens of Rijeka primarily due the vicinity of the border and people's habits to go shopping to Trieste, Italy, Austria and more rarely Germany. A tendency toward "western" world is seen in a great number of advertisements from Italy, but also from Germany or Austria, which addressed people of Rijeka, and which resulted in frequent visits to Trieste, Graz or Munchen due to shopping, given there was a great demand for products from the western market. 
The sign type depends on the type of discourse. The majority of signs were, as it was mentioned above, signs of service industries, shops, due to which $88.1 \%$ of signs belonged to commercial discourse, which was not by accident. Also, the purpose was to investigate public spaces where the influence of politics and power was still less expressed. In the research, commercial discourse prevailed because there was certain freedom in expression and language use, especially in the names of cafes, restaurants, small businesses, such as hairdressers because they could have been in private ownership.

Therefore, the most tangible answers collected were to the following questions: 1 Who put the signs? 2 Where were the signs put? 3 What was their function? (Coulmas, 2009:15). An individual without the influence of the government put the signs, and although he/she lived in the socialist system where the term capitalism had a negative connotation, he/she used signs in the English language to show belonging to the international scene, which guaranteed the product quality. For instance, the menu of "Rozi bar" offered: American pizza, American hotdog because the name itself guarantees good quality and indicates that the sign owner was informed. These signs addressed passers-by, city citizens given that there were in the public area with the function of informing about their offer. Also, observing symbolically, these signs refered to openness toward the world and acceptance of foreign development directions. Using these examples, in this period, there is a visible relationship between relationship between the linguistic landscape and state ideology. People existentially need signs in space in order to know what they are allowed, that is what they are not allowed to do. In accordance with that, the objects of the landscape as signs can pinpoint to ideology outside the function for which it was created. For example, the Coca-Cola sign is not just a sign of commerical advertising, but also an indicator that shows that it is the country where the socialist regime was not in place. In the period from 1945 to 1991 the signs were changing. It was important to express collective identity using signs, which could be expressed verbally or iconically.

Table 2. Collective idenity characteristics

\begin{tabular}{|l|c|c|}
\hline $\begin{array}{l}\text { Collective idenity } \\
\text { characteristics }\end{array}$ & Frequency & Percentage \\
\hline Verbal & 7 & 43.7 \\
\hline Iconic & 9 & 56.3 \\
\hline Total & 16 & 100.0 \\
\hline
\end{tabular}

An example of collective identity in a language and in images was seen in the following example. Namely, it was about the banner that encourages women to vote: "Žene. Glasajmo za daljnju izgradnju socijalizma, za mir i aktivnu suradnju među narodima, za bolji život nas i naših porodica." (in English: Women. Let's vote for further growth of socialism, for peace and active cooperation among nations, for better life of us and our families. 
The first two words were written in big red letters on a white background, whereas other words were of a smaller font and written in black on a light blue background. Infromative character came out from the text itself that belongs to a political discourse, while symbolics were seen in red color, which was a symbol of the Communist International. The banner background was light blue, which symbolized blue sky (freedom), on which white clouds were emphasized. The banner was divied by a white line vertically, in the middle, forming two rectangles. In the left and right part of the rectangle there were photographs of the female worker (dressed in workwear) and a woman from a village (dressed in a folk costume). At the bottom, on the left side, on a red background, the date of the elections was written in big white figures, while in the upper right corner a Yugoslav flag was fluttering, whose flagpole represented a white line that divided the banner in two parts. Besides, the informative message this banner had a symbolic function, as well. Blue, white and red color were colors of the flag of Yugoslavia that symbolized the state, but at the same time it represented the image of collective identity (identification with flag, state symbol) and there was no difference between people from rural and urban areas. Everybody was the same (folk costume - workwear). These characteristics of a national identity were noticed in post war years. Out of 16 advertisements that were chosen from that period and from that domain, $43 \%$ of them had a linguistic feature, and $56.3 \%$ of the rest had characteristics of an image. It shows equal importance of words and images in expressing characteristics that affected the foundation of collective identity. All signs were monoligual, that is they were only in the Croatian language.

Figure 2. A banner (University Library Rijeka)

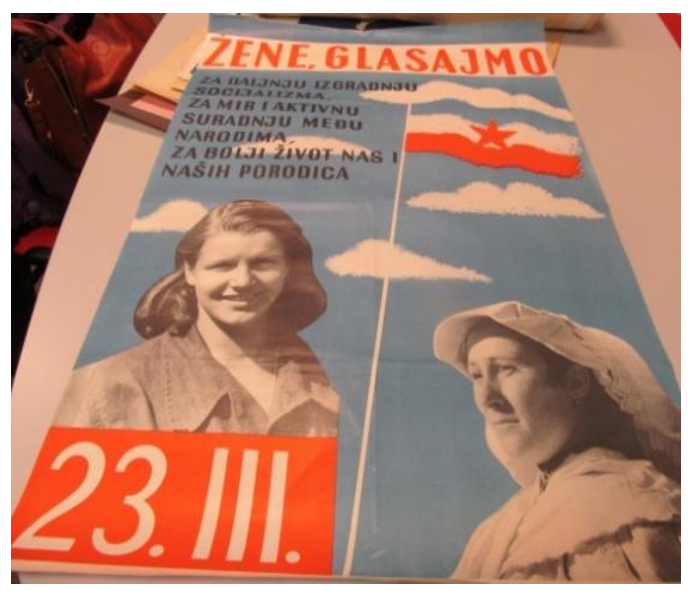

Source: University Library Rijeka 
In the following table (Table 3) the order of languages on signs is displayed.

Table 3: Order of languages (in percentages )

\begin{tabular}{|l|c|c|c|}
\hline Language & First & Second & Third \\
\hline Croato-Serbian & 78.2 & 16.8 & 1.0 \\
\hline Italian & 8.9 & 6.9 & - \\
\hline English & 6.9 & 20.8 & $8-9$ \\
\hline Russian & 2.0 & 3.0 & - \\
\hline Hungarian & 1.0 & - & - \\
\hline French & 2.0 & 5.0 & 1.0 \\
\hline German & - & 9.9 & - \\
\hline \multicolumn{2}{|c|}{ Source: Authors }
\end{tabular}

In Rijeka, besides Croato-Serbian, which was the dominant language, the majority of signs were bilingual (49.5\%), while monoligualism accounted for $34.7 \%$ of these. Next to bilingual and monolingual signs, there were signs that included three languages $(15.8 \%)$. Concerning monolingual signs, the Italian language occured in less than $9 \%$ of samples. Italian was in the first place when it comes to the names of stores. These were actually advertisements of Italian stores that were put in local newspapers, in the Novi list and they had, without exception, a commercial role. Italian was encountered as the first language in the domain of cullture. Italian theatre plays were advertised firstly in the Italian language, while the translation was in the Croatian. The majority of samples $(78.2 \%)$ had Croato-Serbian as the first language. The signs in English and French were found as the first, second and third language. The English language as first (6.9\%), and second language $(20.8 \%)$ was most frequently encountered in titles of cosmetic products and alcoholic drinks (names of French producers). Hungarian names were just witness to passed times. The German language occured as the second language on signs $(9.9 \%)$ in the domain of trade and products, as well as tourism. German companies advertised their services and products in Croatian newspapers, while in tourist brochures, city maps or in leisure activities on offer German was used. English and German were used for tourist purposes given that Rijeka was a transit city back then. It should not be skipped that Rijeka was a tourist city as well, in which there was a substantial number of sailors. Changes in the lingustic landscape of Rijeka were noted after the 80's of the 20th century. Private ownership was allowed. Opening in private enterpreneurship was encouraged from different areas and greate and greater openness toward the western market. Openness toward trends from capitalist countries was present in the Rijeka lingusitc landscape in that sense that next to foreign names, mostly objects in private ownership, there were advertisments in public newspapers such as , Rajčice na talijanski način" (Tomatoes in the Italian way)". "From now on in Rijeka, too: Jeans Jakne - roccobarocco, Blue Cottone - neobarroco" (the Novi List, 25 June 1984, P. 15) music manifestations accompanied by hosting foreign bands that were advertised in the city public area. All these areas refer to opening of the state toward west and the western market. 


\section{Conclusion}

One of the basic indicators of a language policy and language ideology is the difference between the official and private sign, because it gives us an insight into who put the signs, who these signs addressed and what their function was. The choice of language and the postion of language shows power relations. In our case the choise of language and its position indicateed the dominance of the Croatian language, which was particularly emphasized in Rijeka, given that it was an Italian city under the Hungarian crown till 1918. From 1918 to 1943, the city is entirely Italian, and after that, till 1945, under German occupation. The presence of multilinguality (Croato-Italian) was emphasized after the war ended, given that all official titles, streets were bilingual. Bilingualism disappeared as a consequence of a massive exodus of Italians, although the Italian community was still vibrant: both schools in Italian and Italian drama were founded. Once indigenous population became a minority. Multilingualism did not have an important role as much as collective identity and class consciousness, whose author was the state. It addressed population in order to raise class awareness, to establish a collective identity based on brotherhood and equality, as well as to earn respect to fight for national freedom. The paper focused primarily on commercial discourse beacuse there was a certain freedom in the names of signs. In most cases these were: cafes, hairdresser's, tailor's saloon, which prefer names in English in order to emphasize belonging to the international scene, openness to the new, modern guidelines that at the same time guarantee the quality of service. The German and Italian language were found in the domain of tourism, on menus, city maps or tourist programs, or as a foreign private sign in local newspapers.

It might be concluded that multiligualism in the Rijeka area in the period of Socialist Federal Republic of Yugoslavia was not pronounced. The existing biligualism in Croatian and Italian was present in education, culture and tourism. German was found only in the area of tourism, while the presence of the English language in the commerical discourse refered to orientation and tendency toward "west", whereas French was mostly the language of cosmetic products and alcoholic drinks. The Hungarian language that was collected was mainly connected to mooring ships in the Port of Rijeka. 


\section{References}

Backhaus, P. (2007). Linguistic Landscape: A Comparative Study of Urban Multilingualism in Tokyo, 1st ed. Clevedon, U.K.: Multilingual Matter.

Ben-Rafael, E., Shohamy, E., Hasan Amara, M. andTrumper - Hecht, N. (2006). "Linguistic Landscape as Symbolic Construction of the Public Space: The Case of Israel,“ International Journal of Multilingualism, vol.3, pp. 7-30).

Ben-Rafael, E. (2009). A sociological approach to the study of linguistic landscapes. In Shohamy, E. and Gorter, D. (ed.), "Linguistic Landscape: Expanding the Scenery", New York, London: Routledge, pp. 40-54.

Coulmas, F. (2005). Sociolinguistics, The Study of Speaker' Choices, Cambridge: Cambridge University Press.

Edelman, L. J. (2010). Linguistic Landscape in the Netherlands: A study of multilingualism in Amsterdam and Friesland. Amsterdam: University of Amsterdam, doctoralthesis.

Itagi, N. H. and Singh, S.K.(2002b) Introduction. In Itagi, N.H. andSingh, S.K. (ed.), LinguisticLandscapingin India withParticular Reference to the New states: Proseedingsof a Seminar. Mysore: Central Institute of Indian Languageand Mahatma Gandhi International Hindi University pp. ix -xii.

Landry, R.and Bourhis, R.Y. (1997).Linguistic Landscape and ethnographic vitality: An empirical study. Journal of Language and Social Psychologypp. 23:24. 